\title{
Optimization of Hurricane Resistance Wind Turbine Blades
}

\author{
Juan Montañez, BSME, Melvin Nuñez, BSEE, , and Amaury Malave, $\mathrm{PhD}^{1}$ \\ ${ }^{l}$ Universidad Ana G. Mendez Recinto Gurabo, Puerto Rico, ${ }^{l}$, jmontanez91@email.suagm.edu, \\ mnunez52@email.suagm.edu, ajmalave@ suagm.edu
}

\begin{abstract}
Blade design for the Naguabo Punta Lima Wind Farm will be detailed and presented in the wake of the damage caused by Hurricane Maria. An alternative approach for the design of the blades was performed using the data and information collected by the turbines wind sensors during the catastrophe of the hurricane. With these factors, the main objective was a blade design that can withstand the high wind velocities of around $64.6 \mathrm{~m} / \mathrm{s}$, which were the maximum speeds registered by the wind turbines and furthermore, optimize the capability if resisting wind flows of up to using a safety factor. Details for the aerodynamic design are included such as the blade efficiency, airfoil selections, angles of attack, operational conditions, power generation, power coefficient and loads. Three blades were modeled using same energy production capabilities and high wind resistance, providing a starting point for the design and use of extreme wind resistant blades.
\end{abstract}

Keywords-Hurricane, wind speeds, blade, design

\section{INTRODUCTION}

Wind has been an unlimited resource that has been used by mankind for ages. An alternate power source was start to be used when the first windmills were built on the $20^{\text {th }}$ century, therefore wind turbines were introduced. There are two main types of wind turbines, the HAWT model which is a turbine with a shaft mounted horizontally parallel to the ground. Secondly, the VAWT turbine model has a shaft mounted vertically with respect to the ground [3]. The analysis was focused in the HAWT model as it's the model of the turbines installed at the Wind Farm in Naguabo by the Vestas, the model model V100/1.8Mw. This wind farm was severely impacted by the hurricane Maria, since winds gusts off up to 350 $\mathrm{km} / \mathrm{h}$ were recorded. All of the turbines had structural damage, but the most common was blade structural failure as seen in Fig. 1.

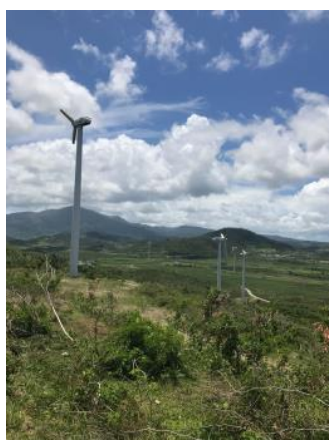

Figure 1: Wind Farm at Punta Lima

Digital Object Identifier (DOI):

http://dx.doi.org/10.18687/LACCEI2019.1.1.344

ISBN: 978-0-9993443-6-1 ISSN: 2414-6390
The objective of this study is to do a preliminary analysis of blades that could withstand extreme wind conditions will having similar power generating capabilities.

For further simplification on the blade design, we used the same parameters and specifications given by the manufacturer as for cut-in wind speed, rated wind speed, cut-out wind speed, rated power, pitch degrees, blade length and max chord, hub diameter and hub height.Some parameters used followed for the design and optimization of the blades. The efficiency of the wind turbine, airfoil designs (thickness, lift to drag coefficient, angles of attack) and materials were prioritized for the design and objectives completion. The governing equations and values for some parameters needed were calculated such as the tip speed ratio (1) which is the relationship that exists between the rotor blade velocity and the relative wind velocity:

(1) $\lambda=\Omega r / V_{w}$

$\lambda=$ Tip speed ratio

$\Omega=$ Rotational velocity (rpm)

$r=$ Radius $(\mathrm{m})$

$V_{w}=$ Wind speed $(\mathrm{m} / \mathrm{s})$

The tip speed ratio was used in the design process and impacts the efficiency drastically. Other relevant values were determined using Q-Blade an open source blade design software which includes all the necessary tools and tests required for an optimum blade aerodynamic design and parameters. The airfoils used in the different designs were sourced form Airfoil Tools which is a website with a catalog of 1,636 different airfoils $[1,2,3]$. Studies for several types of airfoils, thicknesses and lift to drag ratio were crucial when selecting the correct foils for the blade sections development from the root, mid span and tip. Once the blade was partially completed according to the number of sections and the placement of a specific airfoil in each section, the blade was optimized using the Betz limit. The Betz optimization theory indicates the coefficient of which a turbine cannot capture more than 16/27 (0.593) of the kinetic energy in the wind. Once the designs were completely developed and tested for efficiency and power generation, the design coordinates were transferred to Excel Program so the designs could be used in SolidWorks, to draw the blade using the airfoils coordinates, chords and thicknesses. SolidWorks allowed for a more customizable setting for the blades to be viewed and analyzed. The loads testing was performed using Autodesk Fusion 360, another open source program. It allowed an easier materials test and load applications by displaying status, bars and possible solutions to whether the design withstands the applied loads (wind pressures) and the capability of the materials used.

\section{PROCESS}

An analysis of the retrieved data of the hurricane from the wind turbines in Naguabo Punta Lima Wind Farm was done to understand the magnitude of the damage caused, speed winds and relevant information used in the new blade designs.

$17^{\text {th }}$ LACCEI International Multi-Conference for Engineering, Education, and Technology: "Industry, Innovation, And Infrastructure for Sustainable Cities and Communities”, 24-26 July 2019, Jamaica. 
By looking up the company manufacturer and wind turbine model used, we could determine more parameters to be used for the functionality of the new blades on the whole turbine. Some familiarization with the Q-Blade program was needed understand the types of graphs, tests and details of the airfoils, and as of this, airfoil analysis and comprehension were crucial for optimum aerodynamics. Four blade designs were created using the original wind turbine specifications as it follows in Table 1:

Table 1: Wind Turbine Characteristics

\begin{tabular}{|l|l|}
\hline Parameter & Value \\
\hline Capacity (MW) & $1.8 \mathrm{MW}$ \\
\hline Rotor Diameter (m) & $100 \mathrm{~m}$ \\
\hline Blade Length (m) & $49 \mathrm{~m}$ \\
\hline Max Chord (m) & $3.9 \mathrm{~m}$ \\
\hline Cut-in wind speed (m/s) & $4.0 \mathrm{~m} / \mathrm{s}$ \\
\hline Cut-out wind speed & $20.0 \mathrm{~m} / \mathrm{s}$ \\
\hline Rated wind speed & $12 \mathrm{~m} / \mathrm{s}$ \\
\hline $\begin{array}{l}\text { Dynamic Rotational Speed } \\
\text { Range }\end{array}$ & $9.3 \mathrm{rpm}$ to $16.6 \mathrm{rpm}$ \\
\hline Upwind, Hub diameter & $3.3 \mathrm{~m}$ \\
\hline Swept area & $7850 \mathrm{~m}^{2}$ \\
\hline Tip speed ratio start & 1 \\
\hline Tip speed ratio end & 7 \\
\hline $\begin{array}{l}\text { Wind speed (blade efficiency } \\
\text { test) }\end{array}$ & $21 \mathrm{~m} / \mathrm{s}$ \\
\hline Pitch range & $\left(-5^{\circ}\right.$ to $\left.90^{\circ}\right)$. \\
\hline
\end{tabular}

For the first blade model created using the established parameters:

Table 2: Blade 1 Airfoil Sections

\begin{tabular}{|l|l|}
\hline Sections & Description \\
\hline $1-4$ & Circular Foil (100\% thickness), \\
\hline 5 & $\begin{array}{l}5 \text { DU99W405LM airfoil }(40 \% \\
\left.\text { thickness, max } \mathrm{C}_{\mathrm{L}} / \mathrm{C}_{\mathrm{d}} \text { at } 1^{\circ}\right)\end{array}$ \\
\hline $6-7$ & $\begin{array}{l}\text { DUW350LM airfoil }(34.99 \% \\
\left.\text { thickness, max } \mathrm{C}_{\mathrm{L}} / \mathrm{C}_{\mathrm{d}} \text { at } 5^{\circ}\right)\end{array}$ \\
\hline 8 & $\begin{array}{l}\text { DU97W300LM airfoil (30\% } \\
\left.\text { thickness, max } \mathrm{C}_{\mathrm{L}} / \mathrm{C}_{\mathrm{d}} \text { at } 7^{\circ}\right)\end{array}$ \\
\hline $9-10$ & $\begin{array}{l}\text { DU91W2250LM airfoil }(25 \% \\
\left.\text { thickness, max } \mathrm{C}_{\mathrm{L}} / \mathrm{C}_{\mathrm{d}} \text { at } 6^{\circ}\right)\end{array}$ \\
\hline $11-12$ & $\begin{array}{l}\text { DU93W210LM airfoil }(21 \% \\
\left.\text { thickness, max } \mathrm{C}_{\mathrm{L}} / \mathrm{C}_{\mathrm{d}} \text { at } 6^{\circ}\right)\end{array}$ \\
\hline $13-19$ & $\begin{array}{l}13-19 \mathrm{NACA64618} \text { airfoil }(18 \% \\
\left.\text { thickness, max } \mathrm{C}_{\mathrm{L}} / \mathrm{C}_{\mathrm{d}} \text { at } 5^{\circ}\right)\end{array}$ \\
\hline
\end{tabular}

The blade design geometry with all its sections can be seen in Fig. 2:

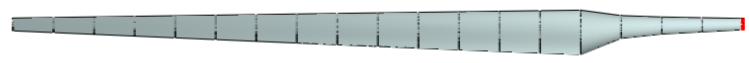

Figure 2: Blade design 1

Blade chord was set to be at $3.9 \mathrm{~m}$ at max at the root and the twist per sections were done automatically by optimizing the blade using the software program and chords. Figure 2 shows the efficiency graph of the blade.

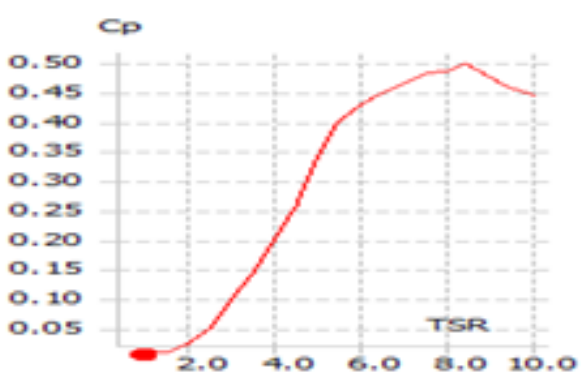

Figure 3. Blade design 1 power coefficient. (TSR 7)

The design performs well and generates a high capacity factor as shown in Fig. 3 but, because the airfoils have a high thickness percentage, this makes the blade heavier increasing the cut-in speed from $4 \mathrm{~m} / \mathrm{s}$ to $5 \mathrm{~m} / \mathrm{s}$.

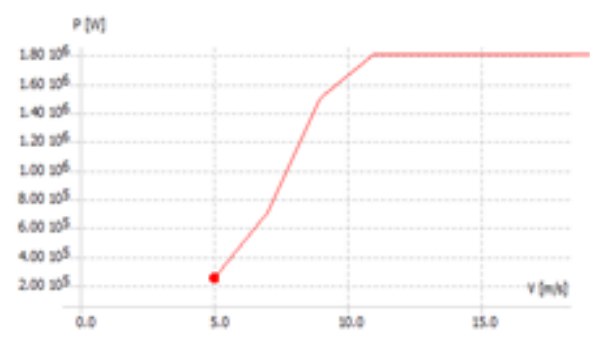

Figure 4. Power generation of design 1

The second blade design was done following the same procedure as the previous one but using different airfoil combinations. 21 sections were created to perform with the best results for this type of design. The sections are described in table 3 and the geometry can be seen in figure 5 .

Table 3: Blade 2 Airfoil Sections

\begin{tabular}{|l|l|}
\hline Sections & Description \\
\hline $1-2$ & $\begin{array}{l}\text { Circular Foils (100\% thickness } \\
\text { at } 1.2 \text { drag coefficient) }\end{array}$ \\
\hline $3-21$ & $\begin{array}{l}\text { GOE } 434 \text { airfoil }(22.70 \% \\
\left.\text { thickness, } \max \mathrm{C}_{\mathrm{L}} / \mathrm{C}_{\mathrm{d}} \text { at } 2.5^{\circ}\right)\end{array}$ \\
\hline
\end{tabular}

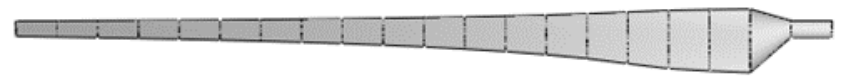

Figure 5: Blade design 2

Twist angles were performed automatically using the optimization options from the software according to the max $C_{L} / C_{d}$ angle using the Betz model. Chord length max was established as the original specifications from the wind turbine.

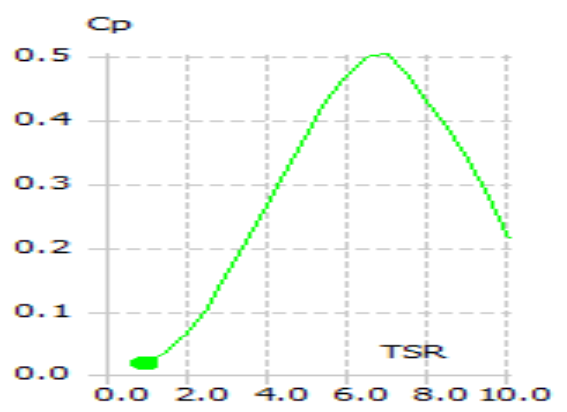

Figure 6. Blade design 2 power coefficient. (TSR=7)

$17^{\text {th }}$ LACCEI International Multi-Conference for Engineering, Education, and Technology: "Industry, Innovation, And Infrastructure for Sustainable Cities and Communities", 24-26 July 2019, Jamaica. 
Fig.6 shows the efficiency of the blade at a tip speed ratio of 7. Fig. 7 represents the generation capacity of the blade and fulfills the parameters specification of the original turbine.

Figure 6: Blade design 2 Power coefficient

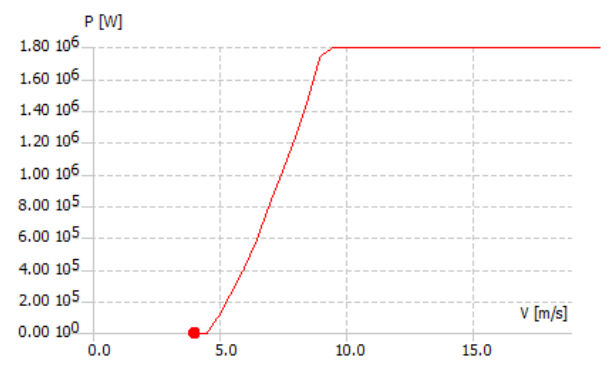

Figure 7: Power generation of design 2

Third blade design continuously followed the same requirements and parameters. The blade has 16 sections from with the descriptions shown in table 4 and the geometry can be seen in figure 8 :

Table 4: Blade 3 Airfoil Sections

\begin{tabular}{|l|l|}
\hline Sections & Description \\
\hline $1-2$ & $\begin{array}{l}\text { Circular Foils (100\% thickness } \\
\text { at 1.2 drag coefficient) }\end{array}$ \\
\hline $3-16$ & $\begin{array}{l}\text { NREL'S S815 airfoil }(26.19 \% \\
\left.\text { thickness, max } C_{L} / C_{d} \text { at } 8^{\circ}\right)\end{array}$ \\
\hline
\end{tabular}

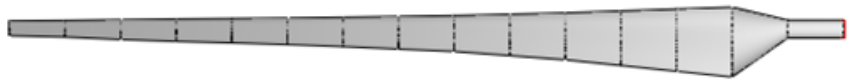

Figure 8: Blade design 3

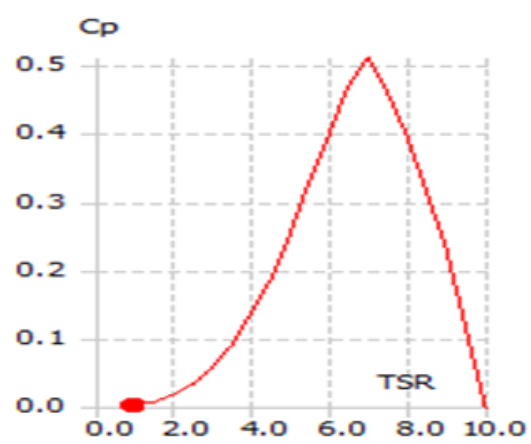

Figure 8: Blade design 3 power coefficient. (TSR 7)

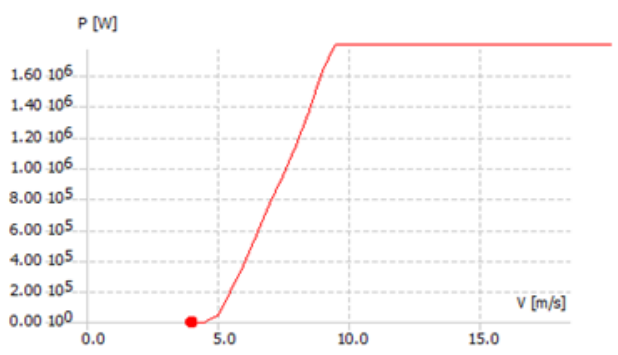

Figure 9: Power generation of design 3

Twist angles were performed automatically using the optimization options from the software according to the max $C_{L} / C_{d}$ angle using the Betz model. Chord length max was established as the original specifications from the wind turbine. Figure 8 shows the efficiency of the blade at a tip speed ratio of 7 . Figure 9 shows the power generation capacity of the blade.

Once the designs were completed and studied using the Qblade program, the data files of the blades and airfoils were transferred to Excel program, were the design coordinates are edited and reconstructed using the airfoils data. This was done and saved in a text delimited and comma delimited format to be used with SolidWorks. One by one, section was transferred and rebuilt in SolidWorks to study the designs and to be able to transfer them to Autodesk Fusion 360 for materials study and loads applications. Due to limitations of materials and compounds in the plastic and glass a specific and complex material was chosen for strength, stresses and safety factor tests. The material selected was Carbon Fiber Reinforced Polymer (CFRP) which is a compound used in the design of aero-dynamical mechanical parts such as helicopter blades, chassis and car parts for better resistance and performance, the material properties are shown in table 5 .

Table 5: Material Properties

\begin{tabular}{|l|l|}
\hline Parameter & Values \\
\hline Density & $1.43 \mathrm{e}-06 \mathrm{~kg} / \mathrm{mm}^{3}$ \\
\hline Young Modulus & $133000 \mathrm{MPa}$ \\
\hline Poisson Ration & 0.39 \\
\hline Yield Strength & $300 \mathrm{MPa}$ \\
\hline Ultimate Tensile Strength & $577 \mathrm{MPa}$ \\
\hline Thermal Conductivity & $0.105 \mathrm{~W} /\left(\mathrm{mm}^{\circ} \mathrm{C}\right)$ \\
\hline Thermal Expansion Coefficient & $9.93 \mathrm{e}-06 /{ }^{\circ} \mathrm{C}$ \\
\hline Specific Heat & $1130 \mathrm{~J} /\left(\mathrm{kg}^{\circ} \mathrm{C}\right)$ \\
\hline
\end{tabular}

Using the maximum air speed flow data collected from the wind turbine blade, the air pressure amount was then converted in to a punctual force by multiplying the wind pressure exerted with each blade area (using the average width due to geometry irregularities) to have the punctual force given in $\mathrm{kN}$. Three wind pressures were selected for the force applying test which included the maximum registered wind speeds at the site were of $64.6 \mathrm{~m} / \mathrm{s}(236 \mathrm{~km} / \mathrm{hr})$ the maximum sustained wind speeds measured and wind gust speeds of $78.23 \mathrm{~m} / \mathrm{s}(283 \mathrm{~km} / \mathrm{hr})$ and $89.40 \mathrm{~m} / \mathrm{s}(321 \mathrm{~km} / \mathrm{hr})$, Maria. Stress calculations and safety factor comparisons were done to solidify the results and validation [6].

\section{RESULTS}

Each blade was design to have a power generation curve similar to the existing blades and power coefficient of 0.5 . After which a stress analysis was done to determine the resistance to exposure to extreme wind conditions as seen in Figure 10. For validation purposes on the designs, we calculated the stresses by estimating the force per unit area.

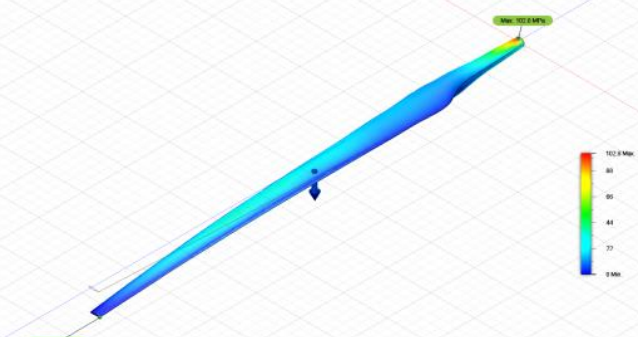

Figure 10: Stress Analysis for Design $1 @ 89.4 \mathrm{~m} / \mathrm{s}$ Each wind blade was subject to each pressure individually using the same material for all. After the study process ended, we compared the

$17^{\text {th }}$ LACCEI International Multi-Conference for Engineering, Education, and Technology: "Industry, Innovation, And Infrastructure for Sustainable Cities and Communities", 24-26 July 2019, Jamaica. 
stress calculations done by the program and compare them to our calculations to see the similarities in our numbers and error percentage. The stress results are displayed in table 6 with calculated values and are well below the yield and ultimate tensile strength. The error percentage was minimal in the first two blade designs when compared to the third one, as a difference or change in a length or chord could have altered the structural design and therefore, the experimental stress calculation. Each pressure exerted in every blade is different depending on the area of it.

Table 6. Stress calculation for each load and blade

\begin{tabular}{|l|l|l|l|}
\hline & \multicolumn{3}{|l|}{ Speed } \\
\hline & $64.6 \mathrm{~m} / \mathrm{s}$ & $78.2 \mathrm{~m} / \mathrm{s}$ & $89.4 \mathrm{~m} / \mathrm{s}$ \\
\hline Design & \multicolumn{3}{|l|}{ Calculated Stress (MPa) } \\
& \multicolumn{2}{l}{} \\
\hline 1 & 53.67 & 78.66 & 102.8 \\
\hline 2 & 65.11 & 88.15 & 115.1 \\
\hline 3 & 65.36 & 95.86 & 125.2 \\
\hline
\end{tabular}

The safety factors were estimating comparing the strength of the blades and the given wind conditions, and are shown for each wind speed are presented in figure 11:

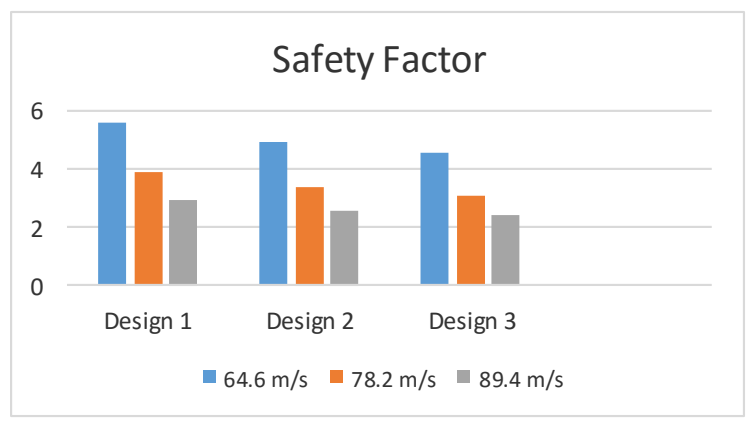

Figure 11: Safety Factor for the blades

The three designs were shown to resist the recorded wind speeds of $64.6 \mathrm{~m} / \mathrm{s}$ to fulfil the most important objective of the research. Further on, the blades were pushed to a limit of $78.2 \mathrm{~m} / \mathrm{s}$ and 89.4 $\mathrm{m} / \mathrm{s}$ for max load resistance to verify the highest wind speeds these blades could take. As the results came in, the design 1 was the most successful one, as it had the highest safety factor in all three of the load studies. This was due to having the thicker air foil percentages of all the three designs. Design 2 managed to withstand all the loads applied with a good safety factor despite the low thickness percentage when compared to Design 1 Lastly Design 3 resulted in a great design, resisting the first load of $64.6 \mathrm{~m} / \mathrm{s}$ but having a lower safety factor in the las two load studies when compared to the previous two designs. The lack of high thickness percentage resulted in a poor durability in the tests. Noise decibels were not taken in consideration, as we strive only for blade design resistance and durability.

\section{CONCLUSION}

The process design of the blades fulfilled all the parameters of the original blade located in Naguabo Punta Lima Wind Farm. Studies in the efficiency, power and lift to drag coefficients were realized individually for each blade design, to find the most optimum design and aerodynamics. As part of the research done, further studies are being made on different materials types, resistances and weight, to help produce a more reliable blade design that can withstand the hurricane Maria winds and even more. Some features in design became relatively new, as there has been not register any other wind turbines that had been struck by winds of more than the ones registered by the Vestas V100/1.8Mw models in Naguabo. Load studies on the wind blades were done, as we strived to perform more research and design optimization to overcome these abnormal weather conditions for the unexpected. As the blades do not have a geometrical design, we calculated the area of the blades by choosing the average chord, thickness and full blade length to design a rectangular equivalent of the blade in which a total static load will be applied in the figure for resistance measurements. The three designs were shown to resist the recorded wind speeds of $64.6 \mathrm{~m} / \mathrm{s}$ to fulfil the most important objective of the research. Further on, the blades were pushed to a limit of $78.2 \mathrm{~m} / \mathrm{s}$ and $89.4 \mathrm{~m} / \mathrm{s}$ for max load resistance to verify the highest wind speeds these blades could take. The lack of high thickness percentage resulted in a poor durability in the tests. Noise decibels were not taken in consideration, as we strive only for blade design resistance and durability. Safety factor numbers in the program delivers a realistic percentage of resistance and safeness in any desired parameters established. Each blade was studied for each load separately to obtain the factors and design effectiveness. Other improvements for the wind turbines in infrastructure should be also a priority in a better design development, as not only the blades were affected, but also the hub, tower and other components.

[1] Jackson, K. J., Zuteck, M. D., Dam, C. P. V., Standish, K. J. \& Berry, D. Innovative design approaches for large wind turbine blades. Wind Energy 8, 141-171 (2005).

[2]Lanzafame, R. \& Messina, M. Optimal wind turbine design to maximize energy production. Proceedings of the Institution of Mechanical Engineers, Part A: Journal of Power and Energy 223, 93-101 (2008).

[3] Manwell, J. F., McGowan, J. G. \& Rogers, A. L. Wind energy explained: theory, design and application. (Wiley, 2011).

[4] Online access > Wind farms > Punta Lima (Puerto Rico). Wind energy database Available at: https://www.thewindpower.net/windfarm_en_19104_puntalima.php. (Accessed: 28th June 2018)

[5] Shubel, P. J. \& Crossley, R. J. Wind Turbine Blade Design. Energies 1-25 (2012)

[6] W. D. Musial and C. (S. Butterfield, "Using Partial Safety Factors in Wind Turbine Design and Testing," pp. 1-12, Jun. 1997.

$17^{\text {th }}$ LACCEI International Multi-Conference for Engineering, Education, and Technology: "Industry, Innovation, And Infrastructure for Sustainable Cities and Communities”, 24-26 July 2019, Jamaica. 